\title{
A Comparative Study of the Effect of Portfolio and Dialogue Journal Assessment on Iranian EFL Learners' Writing Performance
}

\author{
Seiflou Kobra \\ Department of English Language and Literature, Islamic Azad University, Ahar Branch, Ahar, Iran \\ Hashemnezhad Hossein \\ Department of English Language Teaching, Islamic Azad University, Khoy Branch, Khoy, Iran
}

\begin{abstract}
The aim of the present quasi-experimental study is to investigate the effect of dialogue journal assessment and portfolio assessment on Iranian EFL learners' writing performance. To do this, 90 intermediate EFL students from 150 students in Omid -Mofid English Language institute in Khoy were nonrandomly chosen. They were male and female ( 58 females and 32 males) and their age range is between 20-32. Then they were randomly divided into three groups of 30: a control group receiving only the routine instruction, and two experimental groups receiving portfolio and dialogue journal, respectively. Topic based paragraph writing as pretest and posttest were given to the participants of three groups to detect their writing ability at the beginning and at end of study. The result of the study showed that portfolio assessment group, the dialogue journal group and the control group performed significantly different on the post test. Students in portfolio assessment group outperformed than the student in dialogue journal group and performance of dialogue journal group was better than control group in their writing performance. Finally, some implications are provided for EFL teachers, learners, and syllabus designers.
\end{abstract}

Index Terms - alternatives in assessment, EFL writing, portfolio, dialogue journal

\section{INTRODUCTION}

There have been plenty of efforts during last decades to replace traditional and cliché educational methods with innovative and modern methods based on individual and social needs of students in order to educate them to be more innovative and bring about new perspectives toward the development of knowledge and technology. Development of educational methods entails the change of assessment methods. The changes of assessment methods are inevitable issue once the educational methods are being replaced. Through the alternative assessment methods, teacher takes advantage of assessment at the service of better learning so that the assessment is entirely viewed via a different perspective (Rossi, Freeman, \& Lipsey, 1999). The teacher applies the assessment in such a way that may result in learning improvement. The obtained results of assessment provide the teacher with the tools to recognize students' learning problems as well as her/his own teaching shortages so that s/he could take the required measures to remove the deficiency. Furthermore, the method can favorably strengthen students' motivation for learning and make them aware of weaknesses. Alternatives in assessment, in the present study, include portfolio and dialogue journal assessment.

Portfolio assessment is the most effective technique which is used in the domain of teaching and learning and assessing of English Foreign Language (EFL) writing. According to Paulson and Paulson (1991), portfolios demonstrate efforts, progress, and achievements of learners in one or more areas. Portfolio assessment is an on-going process that includes a procedure. Teachers use this procedure for planning, collecting and analyzing a collection of student's work (Abdul Smad, 2013). The main goals of portfolio assessment are encouraged learners to take responsibility of their own learning, to promote students involvement in assessment, improve student-teacher relationship, fosters learner autonomy, increases motivation of the students, and facilitate cooperative learning activities (Tabatabaei \& Asefi, 2012).

Another non-traditional form of alternative assessment is dialogue journal. Dialogue journals are written conversations between students and teacher or student, kept in a notebook or on a computer. Teacher and student or student and student write back and forth regularly during period of time (voit, 2009). Teacher does not assigned topic to students. Students can write about topic in which they are interested. Teacher doesn't correct students' errors. Dialogue journal has several advantages. Garmon (2001) asserts that it facilitates learning of course material, promote selfreflection and self-understanding, procedural conveniences and benefits, opportunity to express ideas, get feedback on ideas and questions, improve student-teacher relationship.

The primary objective of this study is presenting strategies to improve writing performance via utilization of Portfolio assessment and Dialogue journal assessment. 
The specific objective of this study is to investigate whether using dialogue journal or portfolio assessment can affect the overall writing performance of Iranian EFL learners. This study also aims to find possible existing difference between effect of portfolio and dialogue journal assessment to improve students' writing in Iranian writing classes.

\section{A. Significance and Purpose of the Study}

Writing pedagogy has been one of the greatest challenges that English language teachers encounter in their curriculum. For learners to succeed in writing in EFL, the focus is mainly on class activities which provide the learners with opportunities for being exposed to language. They also could reflect on English discourse and produce language (Ammon, 1985). Such activities composed frequent writing, with guidance and feed-back. Therefore dialogue journal and portfolio can be an effective method in teaching of writing to EFL learners.

There is a lot of research done on portfolio and dialogue in Iran; however, the findings of those are not applied in practice. So in this study, we tried to fill the gap between science and practice. It was hoped that fulfillment of the above aims would help to provide EFL teachers with invaluable information concerning portfolio and dialogue journal assessment as an essential teaching method to improve their students' writing ability.

The primary objective of this study is presenting strategies to improve writing performance via utilization of Portfolio and Dialogue journal assessment. The specific objectives of this study are to investigate whether using dialogue journal or portfolio assessment can affect the overall writing performance of Iranian EFL learners. This study also aims to find possible existing difference between effect of Portfolio and Dialogue journal assessment to improve students' writing in Iranian writing classes.

Unfortunately in our country, according to norms, the process of evaluating just consists of final evaluation happening at the end of course (Mohammadi, 2013). In this method, the efforts of teacher, student, parents and all educational system are focused on final exams and their grades, and all these efforts are summarized in one or two digits mark. This grade is not only the criterion of judgment but is a kind of evaluation of teacher, parents and educational system performance. Undoubtedly, the results of these kinds of decision making are not accurate and may have horrible consequence.

Today we need evaluating systems that take students into account more than traditional assessment. To do so, we use dialogue journal and portfolio assessment. These forms of assessment enable teachers to modify their teaching and make learning meaningful in the classroom. Teachers can also use them as the means of gathering information about students' progress and achievement, help teachers to modify their teaching, and make learning more meaningful in English writing classroom (Chastain, 2004). Also these forms of assessments are in-service of education, teaching and learning.

\section{B. Research Questions and Hypotheses}

Based on the above mentioned problem, the research attempts to answer the following main questions:

$\mathrm{Q}_{1}$ : Dose portfolio assessment have any effect on Iranian EFL learners' writing performance?

$\mathrm{Q}_{2}$ : Dose Dialogue journal have any effect on Iranian EFL learners' writing performance?

$\mathrm{Q}_{3}$ : Are there statistical difference between the effect of dialogue journal and portfolio assessment on Iranian EFL learners writing performance?

With respect to the research questions, the following hypotheses are proposed:

$\mathrm{H}_{1}$ : Dialogue journal has some effect on Iranian EFL students' writing performance.

$\mathrm{H}_{2}$ : Portfolio assessment has some effect on Iranian EFL students' writing performance.

$\mathrm{H}_{3}$ : There are statistical differences between the effect of dialogue journal and portfolio assessment types in Iranian EFL learners' writing performance.

\section{REVIEW OF LITERATURE}

\section{A. Theoretical Study}

In the last two decades, evaluation has undergone a major change. That is, it shifts from testing to assessment. Evaluation contains an integration of instruction and assessment. According to butler (2001), evaluation is defined as the act of information collection to get a better understanding of others for the purpose of more effective instruction. Formal/traditional type of evaluation measured point in time skills and facts (Schackelford, 1996). It was based on objective tests in which students apply lower level thinking skills (Anderson, 1998). There is, in fact, neither collaboration nor participation of students in traditional forms of assessment. It is only teacher who decides what and how to teach (Porter \& Cleland, 1995).

The alternative assessment is a method in contrast to the traditional forms. It is an attempt to find out students' knowledge, skills, and growth, as well (Pierce \& O'Malley, 1992). Through alternative assessment, the progress of both learners and instructors is judged; therefore, they could develop their reflective skills. Portfolio, the most commonly used kind of alternative assessment, collects students' work to show their efforts, progress, and achievements (Arter \& Spandel, 1992). As a facilitator, the teacher is required to be aware of students' needs and proficiency level to provide the appropriate tasks for them. Applying the method, the habits of self- reflection, self-direction, and self- evaluation are constructed in students and their autonomy grows (Brown, 2000). Portfolio assessment helps students to be life- time 
learners. Dialogue journal is another type of alternative assessment. It is a regular written conversation between teacher and students (Peyton, 1993). Students are free in dialogue journal on topic, time, and quantity of their writing without fear of being evaluated (Hyland, 1990).

\section{B. Empirical Studies}

Choochaei, Tavakoli, and Nejad Ansari (2010) in a research examined the effect of portfolio assessment on Iranian EFL students' essay writing. The result demonstrated that portfolio assessment had positive influence on learners' essay writing.

Lee Geok Imm (1997) examined the effects of dialogue journal writing on the development of ESL students' writing skills. He found that dialogue journal writing had enabled the learners to develop their writing products qualitatively and quantitatively. In addition, this study indicated that dialogue journal writing encourage and help ESL students to improve their writing skills.

Kaitlyn Datzman (2009) investigated the impact of dialogue journal writing on the writing performance. The finding suggested that the participants who participated in the journal writing showed greater improvement in their writing. The development in their writing indicated this might be an effective strategy for improving writing skill of English language learners.

Massoudi and Hashemnezhad (2013) examined the effect of dialogue journals and traditional product writing on Iranian EFL learners' writing ability in term of using appropriate preposition and subject- verb agreement. The finding showed that although dialogue journals improved students' writing ability, the amount of improvement was not so significant in contrast with traditional product writing. They concluded that dialogue journal could use as an instrument for improving writing skills and decreasing writing apprehension.

Although there have been a good number of studies on portfolio or dialogue journal assessment, there seems to be little research on comparative form. Hemmati and Soltanpour (2012) compared the effect of reflective learning portfolio (RIP) and dialogue journal writing on Iranian EFL learners' writing performance. The results of posttests showed that students in the RLP group outperformed those in DJW group.

\section{METHOD}

\section{A. Participant}

This study was conducted at Omid -Mofid English Language Institute in Khoy, Iran. The participants of this study comprised 90 intermediate EFL students (30 for each three groups) who were non-randomly selected out of $150 \mathrm{EFL}$ students. In order to make sure that the participants were homogeneous with regard to their language proficiency, Nelson test was administrated to participants. The participants included 19 females and 11 males in the portfolio group, 19 women and 11 men in the DJW group, and 19 females and 11 males in the control group. Participants were randomly assigned into groups of 30: two experimental groups received the treatment (portfolio and dialogue journal) while the other served as the control group and received only the routine instruction. The participants' ages ranged from 20 to 32 years. They were all bilinguals (Azeri-Persian) and they were almost equal regarding their cultural and educational background.

In order to provide uniformity of instruction, the teacher and text books were the same for all three groups.

\section{B. Instrumentation}

According to the aim of the study, the following instruments for collecting the relevant data were utilized:

Nelson English language test: The Nelson300 D test was administered to detect proficiency levels of learners and to prove their homogeneity. It consisted of 50 multiple-choice items, including 37 questions of structures, 7 questions of lexical and 5 questions of pronunciation. Participants were asked to answer the questions in 40 minutes. The Nelson test is nearly common and standardized EFL proficiency test and its reliability and validity was estimated by other researchers.

Text Book: The research textbook is entitle 'Top Notch 3B. English for today's world' by Saslow and Ascher (2006).

Topic-based Paragraph Writings as pre-test and post- test: Researchers took 30 argumentative (agree or disagree) writing topics. They believed that argumentative topics seemed more suitable for students since students could express their thoughts and feelings freely. At the beginning of the study, two topics were chosen by the researchers as pre- test. Also, two topics were chosen as post- test.

The pretest was conducted before the dialogue journal and portfolio activity started. The pretest was designed to determine the quality of participants' writing before dialogue and portfolio practice. Students wrote a paragraph. Each paragraph included at least 150 words. They had 60 minutes time to write a topic based paragraph and were allowed to use dictionaries at the time of writing.

The posttest conducted after 16 sessions. The researchers administered a post-test to know whether the difference between groups and also between pretest and posttest is significant.

Analytic Scoring Rubric: The researcher scored the paragraphs according to the rating scale of Jacobs, Zinkgraf, Wormuth, Hatfiel, \& Hughes (1981). The scoring rubric applied in the study consisted of five subscales: mechanic, language use, organization, content and vocabulary. The main section was divided into four subsections. The total score 
for each participant's composition was 100. Researchers would not doubt their validity and reliability because their validity and reliability were already established.

\section{Procedure}

This study was conducted at Omid-Mofid English Language Institute in Khoy, Iran. The class met once a week for one hour and thirty minutes over 16 weeks during winter and spring semester.

This study is a quasi-experimental. Ninety intermediate EFL learners' were non-randomly selected out of 150 learners' in Omid-Mofid English Language Institute in Khoy through purposive sampling technique. First, the Nelson English Test was administered to 150 intermediate EFL learners in a licensed language school to make sure that all participants were homogeneous. They were allowed 40 minutes to complete the Nelson Test. For having more homogeneous groups, students with scores between 27 and 41 were selected in the main phase of the research. Besides, they were asked to write on a topic. It was carried out as a pre-test in order to have participants with the same level of overall writing performance prior to the treatments administration. Students wrote a paragraph. They had 60 minutes time to write a topic based paragraph.

Next, the selected participants were randomly assigned into three groups: two experimental groups (each of them consist 30 students) and one control group (30 students).

The sessions were held one session per week for sixteen weeks. The teacher and the textbook were the same for all three groups. The same instruction presented to 3 groups of samples. The amount of time for all 3 groups was equal. Each of three groups went through different treatments which was explained bellow.

\section{Experimental group one: portfolio}

During the first week, the teachers explained the purpose, design and procedure of portfolio assessment. They explained the importance of self- assessment in process of portfolio and also explained the self- assessment check list and told them how they were going to check themselves and score their own paragraph. This check list that provided based on Bailey and Powell's book (1987 as cited in Moradan \& Hedayati, 2011). The check list contained 10 questions. The questions were based on the researcher expectations of students' learning about paragraph writing. One score was assigned to each question and students checked their own paragraph based on the question and gave themselves one or zero. The total score was 10 .

Having instructed the common materials of the book, the students were asked to write on a topic (agreed upon by the class majority). They had 60 minutes time to write. The first drafts of students' writing were read and examined carefully by the teacher. Next stage included applying teacher's comments on each assignment. In addition, students were provided with some guidelines to review their paragraphs. In the following week, they were required to self-assess their own writing by the means of checklists given by teacher and then checklists were collected. Next week, the researcher retuned the checklists to the students to be revised and redrafted by students themselves based on their own reflections and also the comments given by the teacher. Students wrote their name on the given folders and kept their writings and checklists on them. Once the treatment came to the end, the learners presented a portfolio to the instructor for evaluation. Students could select two out of five papers as their best work for final evaluation.

Evaluating the portfolios was based on analytic rating scales. In line with Jacobs et al. 1981, as cited in Campos (2010). The treatment lasted for 16 sessions.

\section{Experimental group two: dialogue journal}

During the first week, the teacher introduced the concept of dialogue journals and was asked to bring a notebook with themselves. Students were instructed that notebook would be used outside of classroom. This method created a safe environment for the pupils because it removed students' fear and helped them express themselves more effectively in the second or foreign language (Spack \& Sadow, 1983). Researchers gave three topics to students. The researchers motivated students to have discussions by which their interests on various topics were checked. During the whole semester, the teacher was ready to answer their questions and solve their problems. She also wrote a list of words and phrase on the board as students asked about them. At the end of class, the participants were asked to hand in their journals to the teacher. The students were informed that their writing was not going to be corrected, graded or evaluated for grammar. This method provides the learners with the opportunity to get indirect feedback of the teacher in their journal. Moreover, the teacher tried to illustrate the correct usage of grammatical errors in the responses (Peyton, 1991). In the coming week, the teacher gave her comments on writings, and recast their errors by writing correct responses. In that session, students read teacher's responses and answered her questions back. A part of class time was also allocated to their paragraph decoration and arrangements. The same treatment was executed in this group for 16 successive sessions.

Teacher also gave time to decorate their paragraph. The treatment in this group went on like this for sixteen sessions.

\section{Control group}

After teaching the first lesson of the text book, the participants were asked to write a paragraph having a maximum number of 150 words at the class. The writings were collected and corrected by the researcher in red ink at home. The next session, the scored papers were delivered back to the students with some comments on the global mistakes. The compositions were given scores throughout the semester. The same trend continued till the end of semester. 
Finally, after sixteen sessions all subjects were given two topics. The learners took post-test in order for the researchers to learn whether the difference between groups and also between pretest and posttest is significant or not. The scoring procedure for the post-test was quite similar to that of the pre-test.

\section{Design of the Study}

The intent of this study was to find out if dialogue journal and portfolio assessment have any effect on writing performance. This study also aims to investigate difference between effect of portfolio assessment and dialogue journal on Iranian EFL learners' writing performance.

The appropriate design for this study is quasi-experimental method. Ninety intermediate EFL learners' were nonrandomly selected out of 150 learners' in Omid-Mofid English Language Institute in Khoy through purposive sampling technique. To carry out the experiment of the study, participants were randomly assigned into three groups of 30: two experimental groups and one control group. Three groups were nearly the same from viewpoint of sex. Two experimental groups receive the treatment (portfolio and dialogue journal) while control group receives only the routine instruction. The collected data were analyzed by the following methods through Statistical Package for Social Sciences (SPSS version 19). First, Descriptive Statistics was used to determine the mean and standard deviation of the two experimental groups and the control group at two different testing sessions on the pre- test and post-tests. Next an independent sample t-test was run to approve that all 3 groups were not primarily different but, homogeneous. Since descriptive statistics alone were not strong enough to reject or accept the second hypothesis and second question, a oneway ANOVA was applied to assess difference between three groups after the administration of treatment.

\section{RESULT}

This part is provided the descriptive statistics and analysis of the results of the proficiency test and writing pre- and post-tests in both groups as well as the statistical analysis investigating research hypotheses.

\section{A. The Language Proficiency Test}

To homogenize the participants of this study a Nelson English Language Test was done.

150 participants took part in test. Then the samples which their results were one standard deviation above or below the mean took part in this investigation. Table 1 demonstrates the descriptive statistics of the participants' Nelson scores.

TABLE 1

DESCRIPTIVE Statistics OF THE PARTICIPANTS' NELSON ENGLISH LANGUAGE TEST SCORES

\begin{tabular}{llllll}
\hline & $\mathrm{N}$ & Minimum & Maximum & Mean & $S D$ \\
\hline Nelson & 150 & 22 & 49 & 33.90 & 7.631 \\
Valid N (listwise) & 150 & & & & \\
\hline
\end{tabular}

As the table demonstrate, overall mean and standard deviation of the initial participants' Nelson English Language Test scores were 33.90 and 7.631, respectively. From these initial participants, 90 students whose score were between 27 and 41 were selected.

\section{B. Descriptive Statistics of Three Group}

Table 2 demonstrates the descriptive statistics for the participants in three group.

TABLE 2

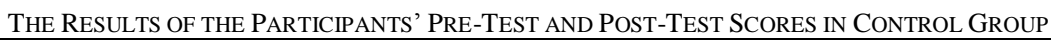

\begin{tabular}{llllll}
\hline & $\mathrm{N}$ & Minimum & Maximum & Mean & $S D$ \\
\hline Pre-Test in Control Group & 30 & 40 & 83 & 59.87 & 11.069 \\
Post-Test in Control Group & 30 & 57 & 100 & 76.87 & 11.066 \\
Pre-Test in EG1 & 30 & 39 & 84 & 59.43 & 11.619 \\
Post-Test in EG1 & 30 & 72 & 100 & 89.43 & 7.394 \\
Pre-Test in EG2 & 30 & 41 & 83 & 59.57 & 11.294 \\
Post-Test in EG2 & 30 & 66 & 100 & 83.33 & 9.241 \\
\hline
\end{tabular}

It can be clearly observed in Table 2 that participants' pre-test mean score in control group was 59.87 with the standard deviation of 11.069. Concerning the post-test, participants' mean score was 76.87 with the standard deviation of 11.066 .

As the table represents, it has been found that students' mean score in EG1, in pre-test, was 59.43 with the standard deviation of 11.619; whereas in the post-test, the first experimental group showed a mean score of 89.43 with the standard deviation of 7.394 .

Furthermore, the students' mean score in EG2, in pre-test, was 59.57 with the standard deviation of 11.294; while in the post-test, the second experimental group had a mean score of 83.33 with the standard deviation of 9.241. 


\section{Writing Pre-test}

To check the homogeneity of the control and two experimental groups in terms of their writing pre-test, an ANOVA on their pre-test scores was run. But, prior to conducting ANOVA, to test the normal distribution of the pre-test scores in each group, the Shapiro-Wilk test was used which is typically tested at the $\alpha=0.05$ level of significance. The p-value is compared to the alpha level (level of significance for the statistic) - and a determination is made as to reject ( $p<\alpha$ ) or retain $(\mathrm{p}>\alpha)$ the research hypothesis. Table 3 indicated the results of the normality test.

TABLE 3

THE RESUlts OF THE SHAPIRO-WILK NORMALITY TEST FOR PRE-TEST SCORES IN THE THREE GROUPS

\begin{tabular}{llll}
\hline & \multicolumn{3}{l}{ Shapiro-Wilk } \\
\cline { 2 - 4 } & Statistic & Df & Sig. \\
\hline Pre-Test CG & .974 & 30 & .645 \\
Pre-Test EG1 & .967 & 30 & .458 \\
Pre-Test EG2 & .955 & 30 & .225 \\
\hline
\end{tabular}

Given that the p-value is higher than 0.05 for three sets of scores, it can be concluded that proficiency test scores in each group are normally distributed. Therefore, the normality assumption was met for this sample.

Finally, the one-way ANOVA was run to investigate the difference in pre-test scores of the participants in three groups the results of which are presented in the Table 4.

TABLE 4

THE ANOVA OF THE PARTICIPANTS' PRE-TEST SCORES IN THE THREE GROUPS

\begin{tabular}{llllll}
\hline & $S S$ & $D f$ & $M S$ & $F$ & Sig. \\
\hline Between Groups & 2.956 & 2 & 1.478 & .012 & .989 \\
Within Groups & 11168.200 & 87 & 128.370 & & \\
Total & 11171.156 & 89 & & & \\
\hline
\end{tabular}

Table 4 indicates that there is not any significant difference among the pre-test scores of the participants in three groups $(\mathrm{p}$-value $=0.989>0.05)$. Therefore, participants in three groups were homogenous.

\section{Statistical Analysis for the First Hypothesis}

The first research question addressed the effect of portfolio assessment on the writing performance of the participants. An independent samples t-test had to be run on the scores obtained from the post-test of the participants in CG and EG1 to answer this research question. Table 5 presents the results of the independent samples t-test.

TABLE 5

CG AND EG1 DIFFERENCE

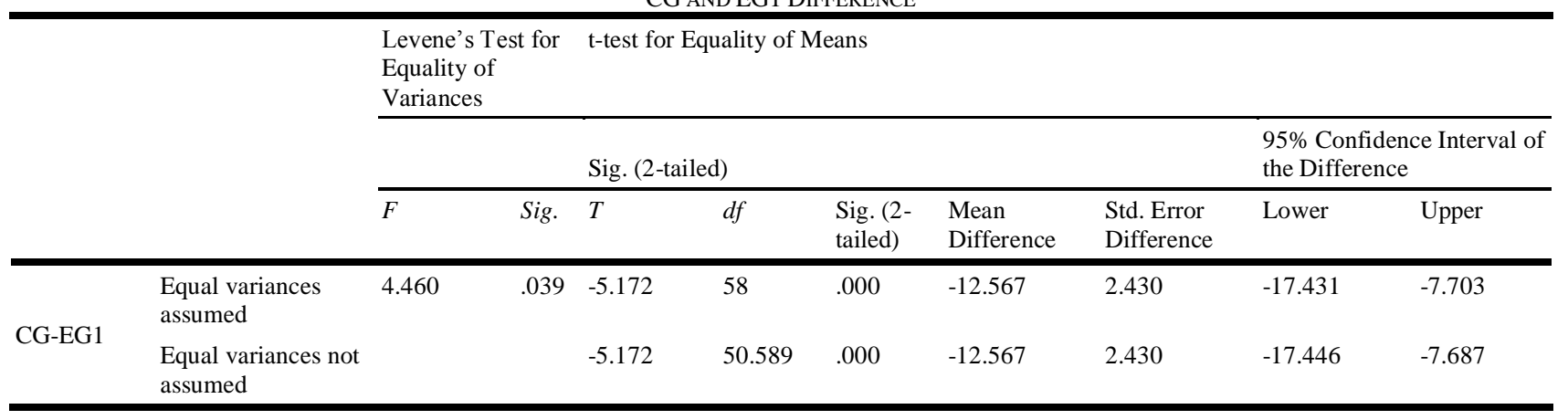

Levene's Test for Equal variances yields a p-value of 0.039. This means that the difference between the variances is statistically significant and the statistics in the second row should be used. The p-value in the second row approaches to 0 which is less than 0.05 and indicates that there is a significant difference in post-test scores of the participants in control and first experimental groups. The amount of mean score of the control group minus mean score of the first experimental group was -12.567 , which revealed better performance of the EG1 in comparison with CG. The 95\% confidence interval for the difference between two means was $(-17.446,-7.687)$. Therefore, the first hypothesis of the study is supported.

\section{E. Statistical Analysis for the Second Hypothesis}

The second research question attempted to investigate the impact of dialogue journal on the writing performance of the participants. Another independent samples t-test was made on the participants' post-test scores in CG and EG2 to check the second hypothesis. Table 6 shows the results of the independent samples t-test. 
TABLE 6

CG AND EG2 DIFFERENCE

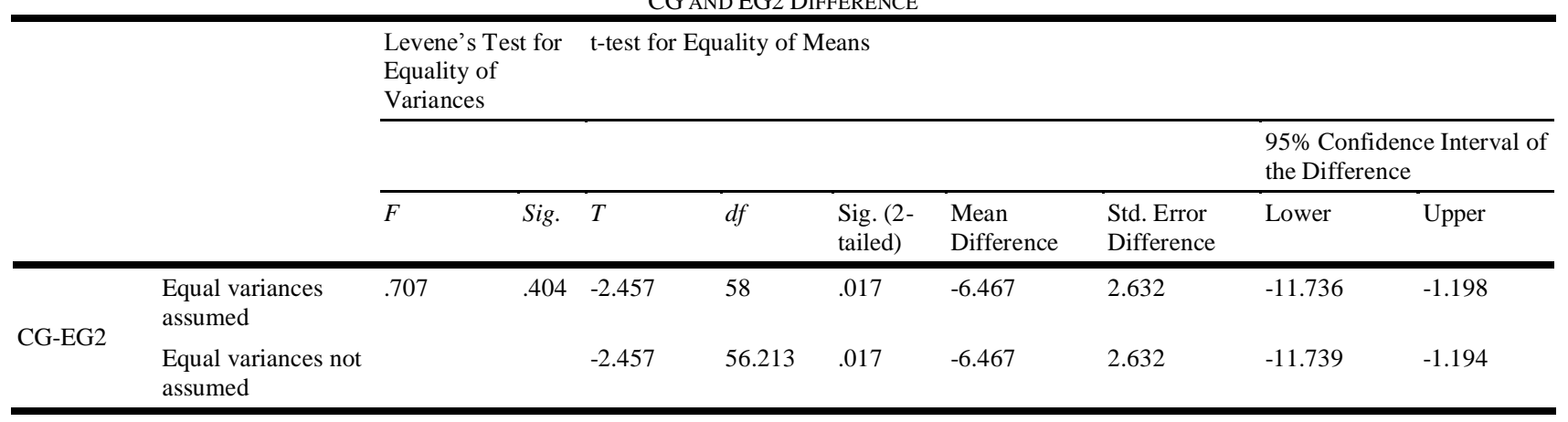

According to Table 6, the p-value of the Levene's Test for Equal variances was 0.404 which shows an insignificant difference between the variances of CG and EG2. Therefore, the statistics in the first row should be employed. The pvalue is equal to 0.017 which is lower than 0.05 and reveals that there is a significant difference in post-test scores of the participants in control and first experimental groups. The amount of mean score of the control group minus mean score of the second experimental group was -6.467 , which indicated better performance of the EG2 in comparison with CG. The $95 \%$ confidence interval for the difference between two means was $(-11.736,-1.198)$. Therefore, the second hypothesis of the study is confirmed.

\section{F. Statistical Analysis for the Third Hypothesis}

The would-be difference between the effects of portfolio assessment and dialogue journal was checked by an independent samples t-test the results of which are presented in Table 7.

TABLE 7

EG1 AND EG2 DIFFERENCE

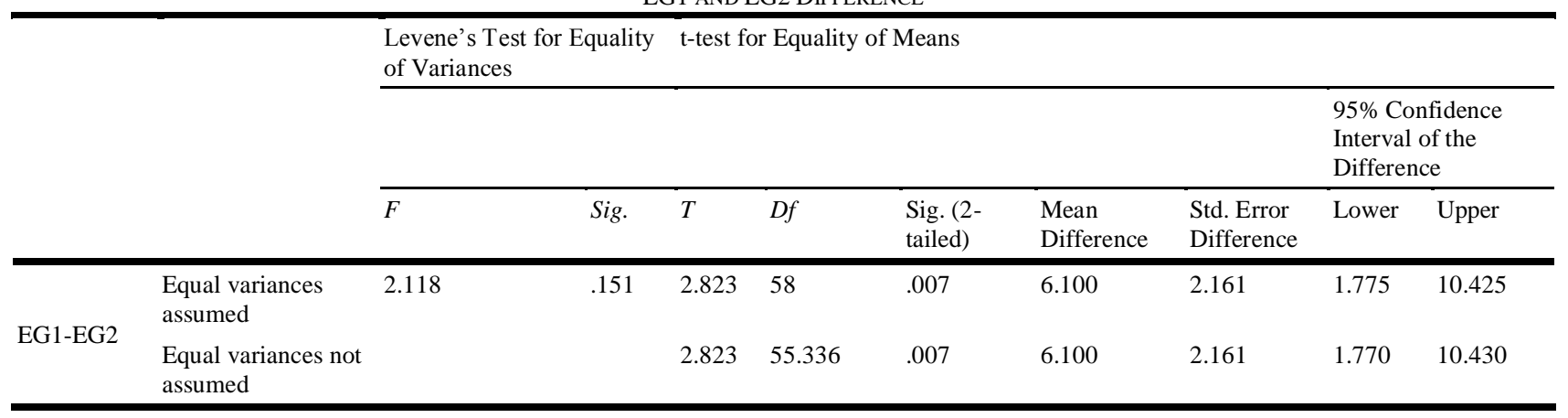

As Table 7 shows, the p-value of the Levene's Test for Equal variances was 0.151 which shows an insignificant difference between the variances of EG1 and EG2. Therefore, the statistics in the first row should be employed. The pvalue in the first row is equal to 0.007 which is lower than 0.05 and yields a significant difference between the effects of portfolio assessment and dialogue journal on writing performance of the participants. The mean score difference of groups was 6.100 and revealed that students who used portfolio assessment outperformed the dialogue journal group. The $95 \%$ confidence interval for the difference between two means is $(1.775,10.425)$.

\section{DISCUSSION}

The present study examined whether dialogue journal and portfolio assessment can affect the writing performance of Iranian EFL learners. The result of statistics confirmed Hypothesis 1 and 2 and showed that portfolio assessment and dialogue journal assessment have some effect on learners' writing performance. Portfolio and dialogue journal assessment not only assess the learners' abilities but also provide them with enough opportunities for learning and development. Also, learners receive some corrective feedbacks which help them to be aware of their weakness and strengths.

Also, the result of study confirmed hypothesis 3 and shows that there are significance differences between dialogue journal assessment and portfolio assessment among Iranian EFL learners' writing performance. The means score of writing in the portfolio assessment group was significantly higher than in dialogue journal group.

Portfolio assessment is the most effective technique which encourages learners to enhance their reflective skill, and provides an opportunity for learners to monitor their own progress, and take more responsibility. In addition, they enable teacher and learner to share the responsibility for setting learning goal learning goals and for evaluating progress toward meeting goal. Self-assessment checklist helps learners to develop sense of independency in writing class and hence their critical thinking skill. 
Findings of the present study are in line with the results of Starck (1999) who examined the impact of portfolio assessment on students' use of accurate grammar and structure during writing, their general writing skills and their attitudes toward writing. The findings of the study indicated when student journals were analyzed, there was positive feedback concerning their attitudes toward writing

Results of the present research approved Spencer's (1999) findings which studied the impact of portfolio evaluation on learner's writing abilities and their orientation about writing. Outcomes indicated that portfolio evaluation had effect on learners' writing competency and it had a consequence on their tendency toward writing.

Findings of the present study were also in the same line with the Yurdabakan and Erdogan (2009) findings who studied the impact of portfolio assessment on reading, listening and writing skills of a group of secondary school students in Turkey. They concluded that that portfolio assessment had significant positive influence on students' writing abilities.

The findings of the present study confirmed the results of Choochaei et al. (2010). They found that portfolio assessment positively affected the students' achievement in their overall writing.

Results of the present study were also supported the findings of the Datzman (2009) who examined the impact of dialogue journal writing on the writing performance and found that the participants who did journal writing showed greater improvement in their writing.

Similarly, the present study confirmed the results of the study conducted Lee Geok Imm (1997) who explored the impact of dialogue journal writing on the improvement of ESL students' writing skills.

In terms of comparing the effects of portfolio assessment and dialogue journal, as far as the researchers know, only one study was conducted by Hemmati and soltanpour (2012). They made comparison between the effect of reflective learning portfolio and dialogue journal writing on Iranian EFL learners' accuracy in writing performance. Outcome of their study was in line with the results of the present research both indicating better performance of the portfolio group in comparison to the dialogue journal group.

The present study, in terms of dialogue journal, reject the result of Massoudi and Hashemnezhad (2013) who examined the effect of dialogue journals and traditional product writing on Iranian EFL learners' writing ability in term of using appropriate preposition and subject- verb agreement. The finding showed that although dialogue journals improved students' writing ability, the amount of improvement was not so significant in contrast with traditional product writing.

\section{Conclusion AND PedAgOgical IMPLiCATIONS}

\section{A. Conclusion}

The present study attempts to investigate whether using dialogue journal and portfolio assessment can affect the writing performance of Iranian EFL learners. This study also aims to investigate possible existing difference between Portfolio and Dialogue journal assessment to improve students' writing in Iranian writing classes.

Results of the hypothesis testing showed that among 3 groups of samples there are important differences in case of results. In case of writing ability no significant difference found among experimental and control group samples before treatment.

Result of this study indicated that there was statistically significant difference among the performances of the three groups in terms of their writing performance. The Post- test comparison revealed that those students who received portfolio assessment and dialogue journal assessment significantly outperformed students who received traditional assessment. The dialogue journal and portfolio assessment were effective in promoting the students' English writing proficiency. The students who were given a dialogue journal and portfolio as an additional activity had better scores in writing than traditional activity. The improvement of the students' writing performance was shown by the result of the posttest from three groups.

Comparison between portfolio assessment and dialogue journal assessment revealed that there was a significant difference between the performances of the two experimental groups in terms of their writing performance. The students who were given a portfolio assessment as an additional activity had better scores in writing than those who were given a dialogue journal as an additional activity.

\section{B. Pedagogical Implication}

The analysis of the data and the findings of the study suggest some pedagogical implications both for the EFL teachers and EFL learners.

\section{Implications for EFL teachers}

Concerning the third research question, this study found that portfolio assessment can be effective in improving writing performance than dialogue journal. This study may encourage ESL educators to implement portfolio assessment in writing classes as a technique to improve writing ability. Also, this research provided valuable insights into how portfolio as a substitute of traditional assessment could be applied in teaching and assessing writing.

If teachers use portfolio assessment, it may increase learner autonomy, critical thinking, and creativity. It is recommended that writing instructors incorporate a portfolio assessment in order to develop EFL students' writing performance. 


\section{Implication for EFL learners}

From the point of EFL learners, portfolio assessment helps EFL learners to develop writing skills through collaborative learning, self-assessment, and taking responsibility in the process of their learning. Portfolio assessment provides students with the opportunities to acquire and construct the habit of self-reflection, self-direction, and selfevaluation. These qualities are all embedded in the portfolio process. Orem (2001) states that portfolio assessment provides ESL students with a chance to practice using the target language in meaningful and authentic contexts.

English language learners could also benefit from the findings of this study. The finding of third question reveals that portfolio assessment as a type of alternative assessment provides the students with opportunity to use the language authentically in a non-threatening environment. This form of assessment helps learner find their strengths and weaknesses, evaluate and analyze their learning process and learn by themselves.

Using portfolio assessment enables learners to become autonomous learners. Learners can become active learners by taking more responsibility in learning and having more involvement in assessment. It helps learners to develop writing performance.

\section{Implication for syllabus designer}

Syllabus designers and material developers can get the insight from the results of this study in designing an appropriate syllabus and material. Also, educational policy-makers should consider the applicability of portfolio assessment in the Iran context. Portfolio can be included in syllabus and materials, to enable students to take responsibility for own learning and increase learners' motivation. It is recommended that syllabus designer and policy maker consider the applicability of portfolio assessment in Iran context and text book in order to develop EFL students' writing performance.

\section{Suggestions for Further Research}

The findings of this study have provided an insight into the usage of alternative assessment specifically portfolio and dialogue journal assessment in classrooms.

However, this study can still be developed and further explored. Below are some recommendations and suggestions for those who are willing to contribute to the present study by conducting studies on finding differences between portfolio and dialogue journal assessment on writing performance.

It is necessary to check the similar results around Iran with the present research. To understand if there is difference between them or not.

This study was conducted to EFL intermediate students. It can be fruitful if other research on the same issue is extended to other levels such as elementary or advanced.

Also, it is recommended to compare the effect of portfolio and dialogue journal on other skills such as reading, listening, and speaking.

Other researches can be done to compare the effect of other alternative assessment techniques on writing skill.

\section{REFERENCES}

[1] Abdul Samad, A. (2013). The use of portfolio as an assessment tool in the Malaysian L2 classroom. International Journal of English Language Education, 1(1), 95-108.

[2] Ammon, P. (1985). Helping children learn to write in English as a Second Language: some observations and some hypotheses. In S. freedman. (Ed.), The Acquisition of Written Language: Response and Revision (PP,65-84). Norwood, NJ: Ablex.

[3] Anderson, S. R. (1998). Why talk about different ways to grade? The shift from traditional assessment to alternative assessment. New Directions for Teaching and Learning, 74(4), 56-60.

[4] Arter, J. A., \& Spandel, V. (1992). Using portfolios of student work in instruction an assessment. Educational Measurement: Issue and Practice, 11(1), 36-44.

[5] Bailey, E., \& Powell, P. (1987). The practical writer with readings. New York: Holt, Rinehart and Winston.

[6] Brown, H. D. (2000). Principles of language learning and teaching. New York: Longman.

[7] Butler, S. (2001). assessment vocabulary. Retrieved from http:// www. ncsu. edu/ science junction/ rout professional/Assessment/ assess.htm1.

[8] Campos, J. (2010). Choosing a good scale to evaluate students' writing. Retrieved 10 March 2012, from http://www.panamatesol.org.

[9] Datzman, K. (2009). Using dialogue journal to improve writing for English language learners. Unpublished M.A thesis. University of Arkansas. http:// www. ncsu. edu/ science junction/ rout.

[10] Garmon, M. A. (2001). The benefits of dialogue journals: What prospective teachers say. Teacher Education Quarterly, 28(4), $37-50$.

[11] Ghoorchaei, B., Tavakoli, M., \& Nejad Ansari, D. (2010). The impact of portfolio assessment on Iranian EFL students"essay writing: A process-oriented approach. Journal of Language Studies, 10 (3), 35.51.

[12] Hemmati, F. \& Soltanpour, F. (2012). A comparison of the effects of reflective learning portfolios and dialog journal writing on Iranian EFL learners' accuracy in writing performance. English Language Teaching, 5(11), 16-19.

[13] Hyland, K. (1990). Providing productive feedback. ELT Journal, 44(4), 279-285.

[14] Jacobs, H., Zinkgraf, S., Wormuth, D., Hatfiel, V., \& Hughes, J. (1981). Testing ESL composition: A practical approach. Rowley, Mass: Newbury House.

[15] Lee, Geok Imm. (1997). The effects of dialogue journal writing on the development students' writing skill. Unpublished MA thesis, University of Kebangssan Malaysia, Malaysia. 
[16] Moradan, A. \& Hedayati, S. N. (2011). The impact of portfolios and conferencing on Iranian EFL learners' writing skill. Journal of English Language Teaching and Learning, 7(8), 116-141.

[17] Mohmmadi, Z. (2013). Program Evaluation on General English Course: A Case Study at Tabriz University. Journal of Language Teaching and Research, 6(4), 1285-1290.

[18] Masoudi, A., \& Hashemnezhad, H. (2013). The effect of dialogue journal writing and traditional product writing on Iranian EFL learners' writing ability. Unpublished master thesis, University of Urmia, Urmia.

[19] Orem, R.A. (2001). Journal writing in adult ESL: Improving practice through reflective writing. New Directions for Adult and Continuing Education, 90, 69-77.

[20] Paulson, P., \& Paulson, L. (1991) Portfolios: stories of knowing. Eric Digest, 2, 308 -495.

[21] Peyton, J. K. (1990). Dialogue journal writing and the acquisition of English grammatical morphology. In J.K. Peyton (Ed.), Students and teachers writing together: Perspectives on journal writing (pp. 67- 97). Alexandria, VA: Teachers of English to Speakers of Other Languages.

[22] Peyton, J. K. (1993). Dialogue Journals: interactive writing to develop language and literacy. Online Resources: Digests. National Center for ESL Literacy Education.http:www.cal.org/resources/digest/peyton 01.html.

[23] Pierce, L. V., \& O'Malley, J. M. (1992). Performance and portfolio assessment for language minority students. In NCELA program information guide series, $9(2)$, http://www.ncela.gwu.edu/pubs/pigs/pig9.htm.

[24] Porter, C., \& Cleland, J. (1995). The portfolio as learning strategy. Portsmouth, NH: Cook Publisher.

[25] Rossi, P. H., Freeman, H. E. \& Lipsey, M. W. (1999). Evaluation: a systematic approach. Newbury Park, USA: Sage Publications.

[26] Saslow, J., \& Ascher, A. (2006). Top Notch 3 B. English for today's world. NY: Pearson Education.

[27] Schackelford, R. (1996). Student Portfolios: A Process/Product Learning and Assessment Strategy. The Technology Teacher, 55(8), p: 31-36.

[28] Spencer, D. M. (1999). An exploration of portfolio assessment and its influence on children's writing. Unpublished master's thesis, Regina University, Canada.

[29] Spack, R., \& Sadow, C. (1983). Student-teacher working journals in ESL composition. TESOL Quarterly, 17(4), 575-591.

[30] Starck, T. L. (1999). Student portfolios: Impact on writing skills and attitudes. Unpublished doctoral thesis, Memphis University. Retrieved from ProQuest Dissertations \& Theses. (UMI Number: 9933451).

[31] Tabatabaei, O., \& Assefi, F. (2012). The effect of portfolio assessment technique on writing performance of EFL Learners. English Language Teaching, 5(5), pp 138-147.

[32] Voit, M, H. (2009). Do dialogue journals with recasts improve the writing skills for adult learners with limited literacy skills?. Master Thesis, Hamline University, Minnesota, .Saint Paul.

[33] Yurdabakan, I., \& Erdogan, T. (2009). The effects of portfolio assessment on reading, listening and writing skills of secondary school prep class students. The Journal of International Social Research, 2(9), 526- 538.

Kobra Seiflou received M.A. degree in Teaching English as a Foreign Language (TEFL) from Islamic Azad University of Ahar. She teaches English in private language institutions in Khoy. Her interests are methodology and language teaching.

Hossein Hashemnezhad is an assistant professor of TEFL at the Islamic Azad University, Khoy Branch, Iran. He has more than 17 years experience in teaching EFL. His research interests are mainly focused on language teaching as well as assessment. He has published and presented papers in national and international conferences and journals. 